\title{
Changes in women's willingnes to work in a tightening labour market: the impact of preferences, wages and individual characteristics
}

Citation for published version (APA):

Cörvers, F., \& Golsteyn, B. H. H. (2003). Changes in women's willingnes to work in a tightening labour market: the impact of preferences, wages and individual characteristics. ROA. ROA Research Memoranda No. 5E https://doi.org/10.26481/umaror.200305E

Document status and date:

Published: 01/01/2003

DOI:

10.26481/umaror.200305E

Document Version:

Publisher's PDF, also known as Version of record

Please check the document version of this publication:

- A submitted manuscript is the version of the article upon submission and before peer-review. There can be important differences between the submitted version and the official published version of record.

People interested in the research are advised to contact the author for the final version of the publication, or visit the DOI to the publisher's website.

- The final author version and the galley proof are versions of the publication after peer review.

- The final published version features the final layout of the paper including the volume, issue and page numbers.

Link to publication

\footnotetext{
General rights rights.

- You may freely distribute the URL identifying the publication in the public portal. please follow below link for the End User Agreement:

www.umlib.nl/taverne-license

Take down policy

If you believe that this document breaches copyright please contact us at:

repository@maastrichtuniversity.nl

providing details and we will investigate your claim.
}

Copyright and moral rights for the publications made accessible in the public portal are retained by the authors and/or other copyright owners and it is a condition of accessing publications that users recognise and abide by the legal requirements associated with these

- Users may download and print one copy of any publication from the public portal for the purpose of private study or research.

- You may not further distribute the material or use it for any profit-making activity or commercial gain

If the publication is distributed under the terms of Article 25fa of the Dutch Copyright Act, indicated by the "Taverne" license above, 


\section{Changes in women's willingness to work in a tightening labour market: the impact of preferences, wages and individual characteristics}

ROA-RM-2003/5E

Frank Cörvers and Bart Golsteyn

* Earlier versions of this paper were presented in 2001 at a seminar at Maastricht University and a conference for labour market researchers in Antwerp. We would like to thank all participants of these sessions for their comments, notably Walter von Trier, Hans Waege, Lex Borghans, Philip Marey and Maarten Vendrik. Furthermore, we would like to thank Albert Bots, Rob Euwals and Andries de Grip for their valuable suggestions.

Research Centre for Education and the Labour Market

Faculty of Economics and Business Administration

Maastricht University

Maastricht, May 2003 
ISBN 90-5321-371-6

Sec03.066.doc 


\section{Contents}

Page

Abstract $\quad$ i

1. Introduction 1

2. Female labour force participation and labour market tightness in the Netherlands 2

3. Data description 4

4. Estimation of the labour supply model 6

5. The willingness to work and the labour force status of women 9

6. Conclusions 13

$\begin{array}{ll}\text { References } & 13\end{array}$

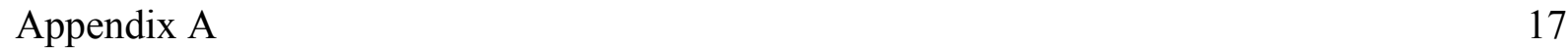

$\begin{array}{ll}\text { Appendix B } & 21\end{array}$

$\begin{array}{ll}\text { Appendix C } & 23\end{array}$

Appendix D 25 



\begin{abstract}
The rapid increase of the female participation rate in the Netherlands gives rise to the hypothesis that the willingness of Dutch women to be employed grew strongly. We predict the number of hours women are willing to work by using the estimated parameters from a multistage least squares Heckit procedure. For a sample of Dutch women between 1994 and 1999 we find that there were significant differences in willingness to work between the employed, the unemployed, discouraged workers, and other non-participants. We also find a positive trend in the willingness to work for these groups, which seems to be almost entirely based on the changing individual characteristics of women, in particular the increase of the average level of education. Changing wages stimulated the working individuals, but had a negative effect on the willingness to work of the non-workers, who were on average lower educated. The effects of wages and preferences nearly outweighed each other for the nonworkers.
\end{abstract}

Key words: Female labour force participation, labour supply, discouraged workers, business cycle, unemployment

JEL-Code: H2, J22 



\section{Introduction}

This paper analyses the remarkable increase in female labour force participation during the second half of the 1990s in the Netherlands, when the Dutch economy was in an upswing. If women adjust their behaviour to the general labour market situation, the flexibility of the labour market may be increased considerably. Due to the 'discouraged worker effect' women may be less inclined to find a job when unemployment rates are high, ${ }^{1}$ whereas in the upward fluctuation of the business cycle they may seek for jobs more actively. For example, Finegan (1981) found for the U.S. that many people are counted as non-participants when unemployment is high, whereas they do enter the labour market when unemployment is low. Darby et al. (2001) tested the significance of these participation reactions to upward and downward fluctuations in the business cycle. In their empirical analysis of four countries ${ }^{2}$ they found empirical evidence for the responses of participation rates to the business cycle.

Instead of looking at the change in participation rates from a macroeconomic perspective, we will analyse the change in the willingness to work of women by the use of a microeconomic framework. In this way, we will try to find the causes of increasing female labour force participation in the Netherlands. The rapid increase of the female participation rate in the Netherlands gives rise to the hypothesis that the willingness of women to be employed grew strongly. This may have been due to both the long-term upward trend in female labour force participation, ${ }^{3}$ which may be related to changing preferences as well as to changing individual characteristics, and the cyclical upturn in the period under consideration, which may be related to the tightening of the labour market and rising wages.

Our contribution to the existing participation literature is threefold. Firstly, we will test the hypothesis of a growing willingness to work by using the estimated parameters from a three-stage least squares Heckit procedure to predict the number of hours women are willing to work in the course of six years. We will also test whether this holds for the 'discouraged workers', who are willing to work but do not search for a job, and for three other groups of women, including the employed, the unemployed and other participants.

Secondly, since the discouraged workers may to some extent have similar characteristics and preferences as the unemployed ${ }^{4}$, we will test whether the differences in the willingness to work between the four groups of women are statistically significant. It may be

1. This phenomenon is known as 'hidden unemployment' since persons who do not search for a job are not counted as unemployed.

2. They also found that the fall of female participation rates during cyclical downturns were significantly larger than the rise of participations rates in upturns. The countries included in the empirical analysis were France, Japan, the United States and Sweden. The 'discouraged worker effect' turned out to be most prevalent in the former three countries, in particular for the 45-54 year age group of women.

3. In general, labour force participation of women has been rising continuously during the last decades, not only in the Netherlands but also in many other countries of the European Union (European Commission, 2001). In the Netherlands, there is a structural upward trend of female labour force participation since the 1960s (Vendrik, 1993; CPB, 2000; WRR, 2000).

4. For an empirical analysis of the distinction between unemployed and discouraged people, see for example Flinn and Heckman (1983), Tano (1991), Gönöl (1991) and Jones and Riddell (1998). The empirical results of these studies are somewhat mixed. In general, one may conclude that the distinction between unemployed and discouraged people matters more for females than for males, and more for younger (till 25 years old) than for older people. 
expected that the workers in the sample are on average most willing to work, followed by the unemployed, the discouraged workers and other non-participants. The women belonging to the last group explicitly stated that they were not willing to work, which allows us to compare their subjective statement on the willingness to work with our empirical findings based on the individual background characteristics (e.g. age, education, having children, having a partner).

Thirdly, to reveal the causes of the estimated changes in the willingness to work between years, we will decompose these changes into changes due to preferences, wages and individual characteristics for the four groups of women over time. Our decomposition technique is partly comparable to that of Gomulka and Stern (1990) and Groot and Pott-Buter (1993), who explicitly include the participation decision in their analysis. However, we focus on the changes in the average number of hours to analyse the development of the willingness to work of the four groups of women. This is another novelty of our analysis.

Section 2 discusses the relationship between the growing female labour force participation and the falling unemployment level (i.e. the tightening of the labour market) in the Netherlands during the last decade of the $20^{\text {th }}$ century. Section 3 refers to the data set used. In Section 4, we will discuss our estimation results and compare these to the results found in other empirical studies. In Section 5, we will test the differences in the willingness to work between the four groups of women mentioned before. We will also analyse the reasons (preferences, wages, individual characteristics) for the positive trend in the willingness to work during the period under consideration. Lastly, we will draw our conclusions in Section 6.

\section{Female labour force participation and labour market tightness in the Netherlands}

The Dutch labour market situation has changed considerably in recent years. Around 1994, the Netherlands experienced a situation with high unemployment rates, whereas in the late 1990s unemployment rates were so low that employers had serious difficulties to find adequate personnel. Due to falling unemployment rates and increasing labour market shortages, the activation of non-working women to participate on the labour market became a matter of great interest in the Netherlands. This held in particular for non-participating women willing to work but not searching for a job, i.e. the 'discouraged workers'. More than two thirds of the discouraged workers is female (ROA, 2001).

In 1991, the female labour force participation rate was 44.9 percent, while in 2000 the participation rate stood at 54.8 percent. The last column of Table 1 shows the yearly increase of female labour force participation rates during the 1990s. Contrary to the rise of the participation rates of women during 1993 and 1994, participation rates of men did not increase during these years. Therefore, participation rates of men seem to be more related to the excess supply on the labour market in those years than the participation rates of women. During the early 1990s, the Netherlands experienced a stagnating economy, which resulted in a peak unemployment rate of 8.5 percent in 1994. For women, the peak was even 11.4 percent in 1994. 
Table 1

Changes in rates of unemployment and labour force participation in the Netherlands, 1992-2000

\begin{tabular}{|c|c|c|c|}
\hline \multirow[t]{2}{*}{ Year } & \multirow{2}{*}{$\begin{array}{r}\text { Change in unemployment } \\
\text { rate }^{\mathrm{a}} \\
\text { Total } \\
\text { in \% points }\end{array}$} & \multicolumn{2}{|c|}{ Change in participation rate } \\
\hline & & $\begin{array}{r}\text { Men } \\
\text { in } \% \text { points }\end{array}$ & $\begin{array}{l}\text { Women } \\
\text { in } \% \text { points }\end{array}$ \\
\hline 1992 & 0.1 & 0.6 & 0.8 \\
\hline 1993 & 0.6 & 0.0 & 1.3 \\
\hline 1994 & 0.6 & 0.0 & 0.6 \\
\hline 1995 & -0.1 & 0.8 & 1.4 \\
\hline 1996 & -0.4 & 0.3 & 1.0 \\
\hline 1997 & -0.5 & 0.8 & 1.9 \\
\hline 1998 & -0.9 & 0.8 & 1.0 \\
\hline 1999 & -0.5 & 0.4 & 1.5 \\
\hline 2000 & -0.8 & 0.8 & 2.1 \\
\hline
\end{tabular}

a. Total unemployment as a percentage of the labour force (15 to 65 years old), change is relative to $\mathrm{t}-1 .{ }^{5}$

b. Labour force as a percentage of the working-age population (15 to 65 years old), change is relative to $\mathrm{t}-1$.

Source: Labour Force Survey (1991-2000), Statistics Netherlands

The excess of labour supply over demand in a recessional period decreased the chances of getting a job and tended to push down real wages. As a result the expected benefits of job search declined, which led to a decrease in search activities. Unemployed people and people who would otherwise have entered the labour force became 'discouraged' and remained outside the labour force. By definition, discouraged workers are willing to accept a job but do not search for work. The loose labour market of 1994, with relatively many discouraged workers, gradually switched to a tight labour market during the next few years. In 2000 the unemployment rate had fallen to 3.8 percent (5.4 percent for women). The percentage of discouraged workers in the population also decreased: the number of 'discouraged workers' fell from 327,500 in 1994 (3.6 percent of the population) to 216,000 in 1999 (2.3 percent of the population). ${ }^{6}$

For two reasons, female labour force participation rates continued to increase during the 1990s, despite the loose labour market in 1993 and 1994. Firstly, as stated above, there was a structural upward trend of the female labour force participation rate during the last three decades, whereas for men the overall trend during this period was downward (WRR, 2000). Therefore it is not surprising that the rise of the female labour force participation rate was less disturbed by a recession than the relatively recent upward movement of the male labour force participation rate in the Netherlands. Secondly, if a husband in a traditional family lost his job

5. In Table 1, unemployment is measured according to the official definition of Statistics Netherlands, in which individuals are only counted as unemployed when they have no job of 12 hours per week or more and are searching for one. In the next sections of this paper, the international definition of unemployment is used, i.e. without the 12-hours border.

6. The population is here restricted to all individuals between 15 and 64 years old and excludes those in initial education. See ROA (2001), chapter 4. 
and became unemployed during the recession years in the Netherlands, other family members, in particular his wife, might have decided to enter the labour force to compensate for the decreased family income. This upward pressure on the female participation rate due to the 'added' female workers partly offsets the downward pressure on the participation rate due to the 'discouraged' female workers. ${ }^{7}$

The above analysis leads to the expectation that the willingness of women to supply themselves on the labour market has increased since 1994. This expectation follows from both the structural upward trend of the female labour force participation rate and the recovery of the Dutch economy - related to the tightening of the labour market - since 1994. The next sections show the results of the empirical microeconomic analysis with regard to the change in the willingness to work of both employed or non-working women between 1994 and 1999.

\section{Data description}

The data set was drawn from the Socio-Economic Panel (SEP) of Statistics Netherlands. This panel contains microdata on about 5,000 Dutch households. We selected the years 1994 to 1999. The selection of these years was dictated by the availability of data sets incorporating more or less the same variables, since not all variables that we needed to conduct our empirical analysis were included in the data sets of the years before 1994. All women in the age of 15 to 65 years old were selected, excluding the self-employed because of the lack of reliable data on their wages. Those attending full-time education and disabled persons were also excluded, since they are preparing for their labour market entry or are not able to work, respectively.

In our sample, we define employed women (E) as those working at least one hour per week. Women are considered to be unemployed (UE) if they have been searching for a job for more than one hour per week during the last four weeks, and are able to start working within three months. Within the group of non-participants (NP), who do not belong to the labour force, we distinguish between women who are willing to work (W) and those who are not (NW). ${ }^{8}$ Women in the former group can be characterised as 'discouraged workers' because they want a job but gave up searching for one. By making use of the panel character of the data, we are able to show the changes in labour force states of women between 1994 and 1999. Table 2 clearly shows that many women started to work during the period between 1994 and 1999. 63 percent of the women who were unemployed in 1994 had a job in 1999. For the non-participating women who had a job in 1999, these percentages are much lower, namely 43 percent of those willing to work in 1994 and 19 percent of those not willing to work in 1994. This can be regarded as a first indication of the larger willingness to work of

7. However, empirical research reveals that the 'discouraged worker effect' clearly dominates the 'added worker effect'. This is straightforward since the former effect is related to a fall in expected real wages during a recession, which affects nearly every household, whereas the latter effect only emerges from families whose normal breadwinner loses a job. For a thorough recent analysis on the 'added worker effect', see Stephens (2001).

8. Based on the question: 'Are you willing to work?' 
the unemployed relative to discouraged workers and other non-participants. In turn, the discouraged workers reveal a larger willingness to work than other non-participants.

Table 2

Changes in labour force states, 1994 to $1999^{9}$

Labour force state in 1999 ,

Total number in 1994* percentage of total number in 1994

E UE NP W NP NW

Labour force state in

$1994 * *$

$\mathrm{E}$

UE

NP W

98

86

63

249

43

NP NW

493

19

$\begin{array}{rrr}2 & 4 & 7 \\ 5 & 14 & 17 \\ 12 & 19 & 25 \\ 3 & 9 & 70\end{array}$

Notes:

*) Total number minus sample outflow

**) $\mathrm{E}=$ employed; $\mathrm{UE}=$ unemployed; NP $\mathrm{W}=$ non-participating willing to work; NP NW = nonparticipating not willing to work

Table 3 presents the levels of education of the total sample of women in the subsequent years. The table indicates that in the sample of 1999 significantly more women were highly educated than in the sample of 1994. This increase in the share of highly educated people is most profound in the working group (see Table A.2 in Appendix A).

Table 3

Sample structure of women according to the level of education, 1994 to $1999^{10}$

\begin{tabular}{lrrrrrr} 
& 1994 & 1995 & 1996 & 1997 & 1998 & 1999 \\
Level of education* & $\%$ & $\%$ & $\%$ & $\%$ & $\%$ & $\%$ \\
& & & & & & \\
\hline & & & & & & \\
PE + LSE & 43.5 & 39.6 & 37.6 & 34.5 & 32.9 & 29.7 \\
HSE & 40.2 & 41.9 & 43 & 44.1 & 44.9 & 46.6 \\
HVE & 13.8 & 15.4 & 16 & 17.2 & 17.5 & 18.4 \\
UvE & 2.5 & 3.1 & 3.4 & 4.2 & 4.7 & 5.4 \\
Total & 100 & 100 & 100 & 100 & 100 & 100 \\
Number & 3378 & 3234 & 3421 & 3278 & 3260 & 3065
\end{tabular}

*) $\mathrm{PE}=$ primary education; LSE = lower secondary education; HSE = higher secondary education; $\mathrm{HVE}=$ higher vocational education; $\mathrm{UvE}=$ university education .

Source: Socio-Economic Panel, Statistics Netherlands

9. In Table A.1 in Appendix A the frequencies and shares of the four groups of women are presented for all years in the period of 1994 to 1999.

10. See Appendix A for an overview of the education levels per group. 
Other variables in the empirical analysis of female labour supply include the average number of hours worked per week, net real wage per hour, other income, age, number and age of children. ${ }^{11}$ The average number of hours worked per week was slightly higher in 1999 than in 1994. This may be the result of both a higher participation rate among women and a higher average number of hours worked by the employed women. The net real wage per hour increased over the years, in particular between 1997 and 1998 (Table A.3). When 1999 is compared with 1994, it can be concluded that the other income (e.g. social insurance benefits and a husband's income) decreased for the employed women but increased for the nonworking women (Table A.8). In addition, the discouraged workers had the highest average number of children (Table A.4) and the lowest average age of the youngest child (Table A.5). The group of discouraged workers had the highest share of women with one or more children: around 74 percent with a peak of 78 percent in 1997. In particular for the groups of working women and other non-participants these shares are much lower. For the latter group, this share decreased over the period (Table A.6). The average age per group of women increased by about two years. Only the unemployed were on average about 4 years older in 1999 than in 1994 (Table A.7).

\section{Estimation of the labour supply model}

The neoclassical static labour supply model that we use is well known and described, among others, by Killingsworth (1983). In this model, each individual has a utility function $U(C, L, X)$ in which $L$ denotes leisure time, $C$ consumption of goods, and $X$ individual attributes. The utility function is assumed to be twice differentiable and concave in $C$ en $L$. Individuals are assumed to maximise utility subject to the budget constraint $C=A+W H$ and time constraint $T=H+L$, in which $A$ denotes the individual's other income, $W$ the net hourly wage rate, $H$ working hours, and $T$ total time. Solving the first-order conditions leads to the labour supply function $H=H(W, A, X)$.

The purpose of this section is to estimate the labour supply behaviour of women and particularly to reveal the change in their preferences to work during a period of time. For our purpose, we estimate a semi-log specification of the labour supply function

$$
H=c+\alpha \ln W+\beta A+\gamma X+\varepsilon
$$

The problem that occurs in estimating labour supply functions is that hours of work are censored. This means that the hours of work variable is zero for the unemployed and nonparticipants. In addition, data on wages are not available for non-working women. This implies that we can only observe wages for employed women. A labour supply function estimated by Ordinary Least Squares would therefore suffer from sample selectivity bias. To correct for this bias, the inverse Mill's ratio is implemented as a variable in the labour supply

11. See Appendix A for an overview of the sample averages of these variables. 
equation (see Heckman, 1974). This ratio is calculated in a probit function for the entire sample of working and non-working women. ${ }^{12}$ The excluded variables in the labour supply function - as opposed to the regressors in the probit function - serve as instruments for the wage in the two-stage least squares technique that is used to calculate the labour supply function (Killingsworth, 1983). Following Mincer (1974), we use tenure, approximated by years of work in the current firm, and level of education (see Table 3) as instruments for the wage. $^{13}$

\section{Table 4}

Estimation results of the labour supply model with hours of work per week as dependent variable, and tenure and education used as instruments for $\ln ^{14}$ (standard errors in parentheses).

\begin{tabular}{|c|c|c|c|c|c|c|}
\hline Variable & 1994 & 1995 & 1996 & 1997 & 1998 & 1999 \\
\hline 'LnW' & $\begin{array}{l}13.35 * * * \\
(2.22)\end{array}$ & $\begin{array}{c}12.35 * * * \\
(2.20)\end{array}$ & $\begin{array}{l}10.50 * * * \\
(1.76)\end{array}$ & $\begin{array}{l}8.13 * * * \\
(1.67)\end{array}$ & $\begin{array}{l}11.92 * * * \\
(1.79)\end{array}$ & $\begin{array}{l}11.74 * * * \\
(2.56)\end{array}$ \\
\hline $\begin{array}{l}\text { Alt. income (year- } \\
\text { ly } / 10,000 \text { ) }\end{array}$ & $\begin{array}{l}-0.39 * * * \\
(0.11)\end{array}$ & $\begin{array}{c}-0.67 * * * \\
(0.12)\end{array}$ & $\begin{array}{l}-0.61 * * * \\
(0.11)\end{array}$ & $\begin{array}{l}-0.56^{* * *} \\
(0.10)\end{array}$ & $\begin{array}{l}-0.60^{* * *} \\
(0.12)\end{array}$ & $\begin{array}{l}-0.59 * * * \\
(0.12)\end{array}$ \\
\hline Child (0-2) & $\begin{array}{l}-10.76^{* * *} \\
(0.82)\end{array}$ & $\begin{array}{c}-10.17 * * * \\
(0.81)\end{array}$ & $\begin{array}{l}-10.37 * * * \\
(0.75)\end{array}$ & $\begin{array}{l}-10.15^{* * * *} \\
(0.72)\end{array}$ & $\begin{array}{l}-10.88 * * * \\
(0.74)\end{array}$ & $\begin{array}{c}-10.84 * * * \\
(0.95)\end{array}$ \\
\hline Child (3-5) & $\begin{array}{l}-10.75^{* * *} \\
(0.95)\end{array}$ & $\begin{array}{c}-9.02 * * * \\
(1.24)\end{array}$ & $\begin{array}{l}-8.29 * * * \\
(1.01)\end{array}$ & $\begin{array}{l}-10.07 * * * \\
(1.01)\end{array}$ & $\begin{array}{l}-9.15^{* * *} \\
(0.95)\end{array}$ & $\begin{array}{c}-10.45^{* * * *} \\
(0.97)\end{array}$ \\
\hline Child (6-12) & $\begin{array}{l}-9.44 * * * \\
(0.84)\end{array}$ & $\begin{array}{c}-6.91 * * * \\
(0.88)\end{array}$ & $\begin{array}{l}-8.31 * * * \\
(0.73)\end{array}$ & $\begin{array}{l}-8.48 * * * \\
(0.76)\end{array}$ & $\begin{array}{l}-8.39 * * * \\
(0.73)\end{array}$ & $\begin{array}{l}-7.83 * * * \\
(0.78)\end{array}$ \\
\hline Child $(>12)$ & $\begin{array}{l}-5.23 * * * \\
(0.90)\end{array}$ & $\begin{array}{c}-4.66 * * * \\
(0.80)\end{array}$ & $\begin{array}{l}-5.56 * * * \\
(0.71)\end{array}$ & $\begin{array}{l}-5.34 * * * \\
(0.69)\end{array}$ & $\begin{array}{l}-3.70 * * * \\
(0.75)\end{array}$ & $\begin{array}{l}-3.39 * * * \\
(0.80)\end{array}$ \\
\hline Age & $\begin{array}{l}-0.10 \\
(0.28)\end{array}$ & $\begin{array}{l}-0.07 \\
(0.28)\end{array}$ & $\begin{array}{r}0.45^{*} \\
(0.23)\end{array}$ & $\begin{array}{l}0.53^{* *} \\
(0.25)\end{array}$ & $\begin{array}{c}0.23 \\
(0.24)\end{array}$ & $\begin{array}{c}0.20 \\
(0.25)\end{array}$ \\
\hline Agesq & $\begin{array}{l}-0.002 \\
(0.004)\end{array}$ & $\begin{array}{r}-0.001 \\
(0.00)\end{array}$ & $\begin{array}{l}-0.01 * * * \\
(0.00)\end{array}$ & $\begin{array}{l}-0.009 * * * \\
(0.003)\end{array}$ & $\begin{array}{l}-0.006^{*} \\
(0.003)\end{array}$ & $\begin{array}{l}-0.006 * * \\
(0.003)\end{array}$ \\
\hline InvMill's & $\begin{array}{l}-10.18 * * * \\
(0.57)\end{array}$ & $\begin{array}{c}-10.81 * * * \\
(0.66)\end{array}$ & $\begin{array}{l}-11.36^{* * *} \\
(0.52)\end{array}$ & $\begin{array}{l}-11.10^{* * * *} \\
(0.51)\end{array}$ & $\begin{array}{l}-8.98 * * * \\
(0.63)\end{array}$ & $\begin{array}{c}-10.00 * * * \\
(1.40)\end{array}$ \\
\hline Intercept & $\begin{array}{c}5.59 \\
(5.14)\end{array}$ & $\begin{array}{c}7.31 \\
(5.68)\end{array}$ & $\begin{array}{c}1.59 \\
(4.49)\end{array}$ & $\begin{array}{c}6.87 \\
(4.99)\end{array}$ & $\begin{array}{c}2.45 \\
(4.52)\end{array}$ & $\begin{array}{c}5.79 \\
(5.98)\end{array}$ \\
\hline R-sq adjusted & 0.41 & 0.36 & 0.42 & 0.40 & 0.34 & 0.26 \\
\hline
\end{tabular}

Note: Robust standard errors in parentheses.

* Significant at the $10 \%$ level; ** Significant at the 5\% level; *** Significant at the $1 \%$ level

12. The results of this probit estimation and wage function parameters are shown in Appendix B.

13. In our estimation procedure, we follow Killingsworth's (1983) so-called 'Procedure VIII'. As he extensively discusses, this procedure has many advantages over the other procedures he mentions. For example, this procedure accounts for discontinuities in the labour supply. Therefore the lowest number of hours individuals will work may be substantially in excess of one hour, which implies that individuals will not work unless the gain of working is large enough to overcome the fixed costs such as appropriate work clothing and the transportation to work.

14. Net hourly wage and other income are corrected for inflation. Other income is measured by the disposable family income (including subsidies, alimony, etc.) minus the income that the woman earned by working. 
The estimated coefficients in Table 4 reveal that having children has a strong negative impact on the hours supplied. The impact of having a child in the age of 0 to 2 years or 3 to 5 years old on hours of work was about the same in 1994 and 1999. For the two older age groups, we can see a more or less downward trend of the impact of having children on the labour supply decision. Moreover, an F-test reveals a significant total effect of age and agesquared for all years. The significant inverse Mill's ratio shows that there is sample selectivity bias, as could be expected. Table 4 shows, lastly, that the net hourly wage has a significantly positive effect on the number of hours worked per week, whereas the effect of other income is significantly negative. Both results are more or less standard. The impact of the net hourly wage on the number of hours worked per week seems to have declined over time, in particular after 1995. The impact of other income on hours worked is greater after 1994.

Given the semi-log labour supply specification, we can derive the uncompensated Marshallian wage elasticity $\left(\mathrm{E}_{\mathrm{W}}\right)$ and income elasticity $\left(\mathrm{E}_{\mathrm{A}}\right)$, using

$$
\begin{aligned}
& \text { (2) } E_{W}=\frac{\partial H}{\partial \ln W} \frac{1}{H}=\frac{\alpha}{H} \\
& \text { (3) } E_{A}=\frac{\partial H}{\partial A} \frac{A}{H}=\beta \frac{A}{H}
\end{aligned}
$$

For the total sample of women in 1994, the average number of working hours per week $H$ was 14.1 and the average other income $A$ was 3.8 (i.e. 38,000 guilders per year ${ }^{15}$ ). By imputing these averages into Equations (2) and (3), the uncompensated wage and income elasticities were calculated for 1994 to 1999. Moreover, the compensated wage elasticities were calculated by subtracting the income elasticities from the uncompensated wage elasticities. These compensated wage elasticities indicate women's preference to substitute own wage earnings for leisure, keeping their income constant.

As was noticed by for example Killingsworth (1983), it is difficult to compare the estimates of the labour supply elasticities in the various empirical studies due to the very different sample selections and estimation techniques. In addition, the elasticities themselves are functions of the average wage rate and hours of work (see above), which are defined and measured quite differently in empirical studies on labour supply.

Our estimated elasticities of Table 5 definitely fall within the broad range in survey studies by for example Killingsworth (1983), Killingsworth and Heckman (1986), and Blundell and MaCurdy (1999). Furthermore, in a survey of Dutch labour supply studies, Theeuwes (1988) concluded that on average female uncompensated wage elasticity was 1.39, income elasticity was -0.16 and compensated wage elasticity was 1.55 . The average wage elasticities are about 0.6 larger than the wage elasticities presented in Table 5, whereas the income elasticities are very much alike. Groot and Pott-Buter (1993) presented even larger wage elasticities than the uncompensated wage elasticities reported by Theeuwes (1988),

15. Note that 1 euro equals 2.20371 guilders. 
namely 2.4 and 2.0 for a sample of married women in 1979 and 1987, respectively. Apart from the fact that the period under consideration and the sample of married women used differed in the study by Groot and Pott-Buter (1993), the differences with our results can be explained by the estimation technique used. As noted by Killingsworth (1983), our estimation procedure allows for a discontinuous labour supply schedule, which typically produces smaller female labour supply elasticities than estimation procedures that assume a continuous labour supply schedule, such as the empirical study by Groot and Pott-Buter (1993). Lastly, van Soest et al. (1990) reported female uncompensated wage elasticities of 0.65 and 0.79 (depending on the model used) and an income elasticity of -0.23 for a cross-section of Dutch households in 1985. Their empirical model accounts for the effect of taxes.

Table 5

Wage and income elasticities, 1994 to 1999

\begin{tabular}{lcccccc}
\hline & 1994 & 1995 & 1996 & 1997 & 1998 & 1999 \\
\hline Uncompensated wage elasticities & 0.95 & 0.88 & 0.74 & 0.58 & 0.85 & 0.83 \\
Income elasticities & -0.11 & -0.18 & -0.16 & -0.15 & -0.16 & -0.16 \\
Compensated wage elasticities & 1.06 & 1.06 & 0.90 & 0.73 & 1.01 & 0.99 \\
\hline
\end{tabular}

Table 5 shows that both uncompensated and compensated wage elasticities were smaller in 1999 than in 1994. Wages elasticities were the smallest in 1997. Income elasticity increased in absolute terms during this period, although it seems to have been fairly stable from 1996 onwards. The changes in both wage and income elasticities imply that it was on average more costly to induce women to increase their supply of hours in 1999 than in 1994, and that women seem to have become more responsive to income from other sources such as their husband's or male partner's income, social security benefits, or alimony.

\section{The willingness to work and the labour force status of women}

The willingness to work of women can at first instance simply be determined by looking at their labour force status. It is reasonable to expect that women who already work, on average have the greatest willingness to work, followed by unemployed women. Both groups of women are considered to be part of the labour force. The remaining women are outside the labour force and can be classified in two groups: those who are willing (and able) to accept a job and those who are not willing. It follows that we can distinguish between four groups of women with a subsequently declining willingness to work: employed, unemployed, nonparticipating but willing to work, and non-participating but not willing to work. In this section, we will test whether the willingness to work of these four groups matches the estimation results of the labour supply model from the previous section. We therefore 
calculate the average number of supplied hours for each group of women - for non-working women as if they were working, see below - by using the estimation results of the last section.

Evidently, unemployed and non-participating women are in reality not working, due to for example the fixed cost of working and the limited availability of (part-time) jobs. Blundell and MaCurdy (1999) referred to various studies that model the transportation cost to work and the wage-hours packages offered by employers. It is, however, not our intention to do so, since we are interested in knowing how the women's preferences developed with respect to their willingness to work between 1994 and 1999. We utilized the difference between predicted and actual working hours that results from fixed costs in the decision to work, to proxy the willingness to work. To test for the differences in willingness to work of the four groups of women, we calculated the average hours that women supply or would supply, irrespective of their participation in the labour market. These were calculated by applying the parameters of the estimated labour supply functions of the period from 1994 to 1999 to the 1994 sample of women. By controlling for changes in individual characteristics of women in subsequent sample years, we intend to reveal the changes in preferences of the four groups of women over time.

Table 6 presents the average estimated working hours for the four groups of women for the period 1994 to 1999 . The estimates reveal the expected order in declining willingness to work for the four groups of women. These differences between the groups of women are significant at the $1 \%$ level. This underlines the importance of the distinction between the four labour force states of women. Therefore, Table 6 also confirms the results found in the abovementioned empirical studies on the distinction between unemployed and discouraged workers. The group of discouraged workers is separated from other non-participants by their answer to a subjective question ('Are you willing to work?'). Our results show that we can predict a positive answer to this question by just looking at the individual characteristics of women. The distinction between unemployed, discouraged workers and other non-participants is also in accordance with the real labour market behaviour of women, as shown in the data description of Section 3.

Table 6

Estimated average number of hours supplied for women of four distinct labour force states, 1994-1999

Mean 1994 Mean 1995 Mean 1996 Mean 1997 Mean 1998 Mean 1999

\begin{tabular}{lcccccc}
\hline Total & 17.4 & 19.0 & 18.0 & 19.1 & 20.1 & 21.6 \\
E & 25.6 & 25.9 & 25.3 & 25.8 & 25.9 & 25.9 \\
UE & 13.8 & 13.8 & 12.3 & 13.3 & 14.6 & 19.5 \\
NP W & 11.1 & 12.5 & 10.7 & 11.2 & 13.5 & 17.3 \\
NP NW & 5.0 & 6.9 & 4.5 & 5.1 & 6.9 & 11.1 \\
\hline
\end{tabular}

Note: $\mathrm{E}=$ employed, $\mathrm{UE}=$ unemployed, $\mathrm{NP} \mathrm{W}=$ non-participating but willing to work, NP NW $=$ non-participating but not willing to work. 
The willingness to work shows an upward trend for the groups of non-working women, with a minimum in 1996. The number of hours women are willing to work increased in particular between 1998 and 1999. Furthermore, it seems that the fixed costs of participation on the labour market requires a minimum of about 12 hours of work per week. Women who may be interested in working less than 12 hours per week, often do not search for a job or will not accept a job for a few hours per week due to the relatively high fixed costs of working. ${ }^{16}$

The difference in the willingness to work over the years can be broken down into the effects of (1) changing individual characteristics, (2) changing preferences, and (3) changing market wages. Table 7 presents the separately calculated effects of changing preferences and changing market wages. We implemented the estimated labour supply and market wage functions of all years to the 1994 sample of women, thereby controlling for individual characteristics. The first column shows the effect of changing preferences. The effect of changing market wages is shown in the first row of every group of women. The diagonal for each group shows the combined effect of changing market wages and preferences.

The first conclusion that can be drawn from Table 7 is that the impact of both changing market wages and changing preferences is smaller than the total effect when changing individual characteristics (see Table 6) are included. Secondly, the impact of changing preferences on the willingness to work was positive for all groups and all years, with the exception of 1996 and 1997 (and 1998 for working women). ${ }^{17}$ The impact of changing market wages on the willingness to work for working women is positive when 1999 is compared to 1994, although the difference is only small. However, the opposite occurs for non-workers: the impact of changing market wages is negative over the whole period. Together, market wages and preferences have had a positive effect for workers, just a small positive effect for unemployed and discouraged workers and a negative effect for all other non-participants. It can be concluded that the positive trend in the willingness to work for non-working women is almost completely due to changing individual characteristics. ${ }^{18}$ Especially the average education level contributed to this shift, as it significantly increased for all groups between 1994 and 1999 (see Appendix A).

In Appendix $\mathrm{C}$ we show by simulation that the participation rate of especially discouraged workers would rise if there was no effect of children on the willingness to work, for example as a result of greatly improved child care facilities. Non-working women would increase their willingness to work significantly more than working women if they did not have an alternative source of income (e.g. became less dependent of their partner). These

16. It should be noticed that our estimation of the labour supply function is based on actual hours worked. Female workers may desire to work more or fewer hours per week than their actual hours worked. Euwals and Van Soest (1999) argued that observed desired hours reflect underlying preferences better than actual hours. However, they found a substantial correlation between desired and actual working hours. They also found that hours restrictions of those who wanted to work were mainly due to involuntary employment and lack of part-time jobs.

17. Almost all differences between years across the rows and columns of Table 7 are significant at the 1\%level.

18. Also Groot and Pott-Buter (1993) found a relatively strong impact of individual characteristics on participation for the Netherlands between 1979 and 1987. 
results show that having children plays an important role in particular for the willingness to work in discouraged workers, and that non-working women in general are more responsive to alternative sources of income than employed women.

\section{Table 7}

The effects of changing market wages and changing preferences on the estimated hours of work, sample of $1994^{19}$

\begin{tabular}{|c|c|c|c|c|c|c|c|}
\hline Group & $\begin{array}{l}\text { Year of } \\
\text { preferences }\end{array}$ & $\begin{array}{l}\text { Wage } \\
1994\end{array}$ & $\begin{array}{r}\text { Wage } \\
1995\end{array}$ & $\begin{array}{r}\text { Wage } \\
1996\end{array}$ & $\begin{array}{l}\text { Wage } \\
1997\end{array}$ & $\begin{array}{c}\text { Wage } \\
1998\end{array}$ & $\begin{array}{r}\text { Wage } \\
1999\end{array}$ \\
\hline \multirow[t]{6}{*}{$\mathrm{E}$} & 1994 & 25.6 & 25.3 & 25.2 & 25.2 & 25.5 & 25.8 \\
\hline & 1995 & 26.0 & 25.9 & & & & \\
\hline & 1996 & 25.0 & & 24.9 & & & \\
\hline & 1997 & 25.3 & & & 25.2 & & \\
\hline & 1998 & 25.2 & & & & 25.4 & \\
\hline & 1999 & 26.7 & & & & & 27.2 \\
\hline \multirow[t]{6}{*}{ UE } & 1994 & 13.8 & 13.2 & 13.4 & 13.4 & 13.2 & 11.8 \\
\hline & 1995 & 14.0 & 13.6 & & & & \\
\hline & 1996 & 12.7 & & 12.5 & & & \\
\hline & 1997 & 13.5 & & & 13.4 & & \\
\hline & 1998 & 14.8 & & & & 14.5 & \\
\hline & 1999 & 15.4 & & & & & 14.0 \\
\hline \multirow[t]{6}{*}{ NP W } & 1994 & 11.1 & 10.6 & 10.7 & 10.9 & 10.6 & 9.1 \\
\hline & 1995 & 11.4 & 11.2 & & & & \\
\hline & 1996 & 10.2 & & 10.1 & & & \\
\hline & 1997 & 10.8 & & & 10.8 & & \\
\hline & 1998 & 12.4 & & & & 12.1 & \\
\hline & 1999 & 12.8 & & & & & 11.3 \\
\hline \multirow[t]{6}{*}{ NP NW } & 1994 & 5.0 & 4.8 & 5.6 & 5.1 & 4.7 & 3.4 \\
\hline & 1995 & 5.2 & 5.2 & & & & \\
\hline & 1996 & 3.3 & & 3.9 & & & \\
\hline & 1997 & 3.8 & & & 4.0 & & \\
\hline & 1998 & 6.0 & & & & 5.9 & \\
\hline & 1999 & 5.6 & & & & & 4.4 \\
\hline
\end{tabular}

Note: $\mathrm{E}=$ employed, $\mathrm{UE}=$ unemployed, $\mathrm{NP} \mathrm{W}=$ non-participating but willing to work, NP $\mathrm{NW}=$ non-participating but not willing to work.

19. An extensive overview of the results is given in Appendix D. 


\section{Conclusions}

In this paper we have analysed to what extent the remarkable increase in female labour participation between 1994 and 1999 in the Netherlands was due to the increase in the willingness to work. We distinguished between the group of working women and three groups of non-working women: unemployed, non-participating but willing to work (discouraged workers), and non-participating but not willing to work. The average number of working hours of the last three groups of women was estimated as if they were employed, which gave an indication of their willingness to work. We analysed whether the willingness to work changed due to changing market wages, changing preferences, or changing individual characteristics during the period under consideration.

We found that there were significant differences between the four groups of women in their willingness to work. The employed were most willing to work, the unemployed were more willing to work than the discouraged workers, and the other non-participants were least willing to work. The group of discouraged workers was separated from the other nonparticipants by the answer to a subjective question ('Are you willing to work?'). Our results show that a positive answer to this question is correlated to both changes in labour force participation over time and the estimated number of hours women are willing to work. The latter implies that we can predict the willingness to work of women by merely looking at their individual characteristics.

Moreover, we found a positive trend in the willingness to work for all groups during the period under consideration. This increase was for only a small part due to changing preferences. The positive trend in the willingness to work for women between 1994 and 1999 seems to be almost entirely based on the changing individual characteristics of women, in particular the increase of the average level of education. Changing wages have stimulated working individuals but have had a negative effect on the willingness to work among nonworkers. This suggests that wages were not only positively affected by the upswing but that the lower educated part of the labour market was at the same time hit by skill-biased technological change (see e.g. Bartel and Sicherman, 1999). This also suggests that the positive trend in female willingness to work was not induced by the cyclical upswing. If combined, the effects of wages and preferences nearly outweigh each other for the unemployed and discouraged workers. The net effect of wages and preferences on other nonparticipants is even negative.

\section{References}

Bartel, A.P. and N. Sicherman (1999), Technological Change and Wages: An Interindustry Analysis, Journal of Political Economy, Vol. 107, pp. 285-325. 
Blundell, R. and T. MaCurdy (1999), Labour Supply: A Review of Alternative Approaches, in O. Ashenfelter and D. Card (eds.), Handbook of Labor Economics, Vol. 3A, North Holland Elsevier, Amsterdam, pp. 1559-1695.

CPB (2000), Macro Economische Verkenning 2001, Centraal Planbureau, Den Haag.

Darby, J., R.A. Hart and M. Vecchi (2001), Labour Force Participation and the Business Cycle: A Comparative Analysis of France, Japan, Sweden and the United States, Japan and the World Economy, Vol. 13, pp. 113-133.

European Commission (2001), Employment in Europe 2001, Luxembourg.

Euwals, R. and A. van Soest (1999), Desired and Actual Labour Supply of Unmarried Men and Women in the Netherlands, Labour Economics, Vol. 6, pp. 95-118.

Finegan, T.A. (1981), Discouraged Workers and Economic Fluctuations, Industrial and Labor Review, Vol. 35, pp. 88-102.

Flinn, C.F. and J.J. Heckman (1983), Are Unemployment and Out of the Labor Force Behaviorally Distinct Labor Force States?, Journal of Labor Economics, Vol. 1, pp. 28-42.

Gomulka, J. and N. Stern (1990), The Employment of Married Women in the United Kingdom 197083, Economica, Vol. 57, pp. 171-199.

Gönül, F. (1992), New Evidence on Whether Unemployment and Out of the Labor Force are Distinct States, Journal of Human Resources, Vol. 27, pp. 329-361.

Groot, W. and H. Pott-Buter (1993), Why Married Women's Labor Supply in the Netherlands Has Increased, De Economist, Vol. 141, pp. 238-255.

Heckman, J.J. (1974), Shadow Prices, Market Wages, and Labor Supply, Econometrica, Vol. 42, pp. 679-694.

Jones, S.R.G. and W.G. Riddell (1998), Unemployment and Labor Force Attachment: A Multistate Analysis of Nonemployment, in J. Haltiwanger, M.E. Manser and R. Topel (eds.), Labor Statistics Measurement Issues, Studies in Income and Wealth, Vol. 60, National Bureau of Economic Research, The University of Chicago Press, Chicago and London, pp. 123-155.

Killingsworth, M.R. (1983), Labor Supply, Cambridge University Press, New York.

Killingsworth, M.R., and J.J. Heckman (1986), Female Labor Supply: A Survey, in O. Ashenfelter and P.R.G. Layard (eds.) Handbook of Labor Economics, Vol.1, North Holland, Amsterdam, pp. 103204.

Mincer, J. (1974), Schooling, Experience and Earnings, National Bureau of Economic Research, Columbia University Press, New York.

ROA (2001), De Arbeidsmarkt naar Opleiding en Beroep tot 2006, ROA-R-2001/8, Research Centre for Education and the Labour Market, Maastricht University.

Stephens Jr., M. (2001), Worker Displacement and the Added Worker Effect, NBER Working Paper No. 8260, Cambridge Mass.

Tano, D.K. (1991), Are Unemployed and out of the Labor Force Behaviorally Distinct Labor Force 
States?, Economics Letters, Vol. 36, pp. 113-117.

Theeuwes, J. (1988), Arbeid en Belastingen, in: Preadviezen van de Koninklijke Vereniging voor de Staathuishoudkunde, Leiden, pp. 111-143.

Van Soest, A., I. Woittiez and A. Kapteyn (1990), Labour Supply, Income Taxes and Hours Restrictions in the Netherlands, Journal of Human Resources, Vol. 25, pp. 517-558.

Vendrik, M. (1993), Collective Habits and Social Norms in Labour Supply, From Micromotives to Macrobehaviour, Dissertation No. 93-18, Maastricht University.

WRR (2000), Doorgroei van Arbeidsparticipatie, Wetenschappelijke Raad voor het Regeringsbeleid, Rapporten aan de Regering, Nr. 57, Den Haag. 



\section{Appendix $\mathbf{A}^{20}$}

Table A.1

Sample structure of women according to four distinct labour force states, 1994 to 1999

\begin{tabular}{lrrrrrrrrrrrrr} 
& \multicolumn{2}{c}{1994} & \multicolumn{1}{c}{1995} & \multicolumn{1}{c}{1996} & \multicolumn{1}{c}{1997} & \multicolumn{1}{c}{1998} & \multicolumn{2}{c}{1999} \\
& Freq & $\%$ & Freq & $\%$ & Freq & $\%$ & Freq & $\%$ & Freq & $\%$ & Freq & $\%$ \\
E & 1866 & 55.2 & 1904 & 58.9 & 2054 & 60 & 2059 & 62.8 & 2107 & 64.6 & 2137 & 66.0 \\
& & & & & & & & & & & & \\
\hline & & & & & & & & & & & & \\
UE & 144 & 4.3 & 144 & 4.5 & 209 & 6.1 & 156 & 4.8 & 128 & 3.9 & 120 & 3.7 \\
NP W & 371 & 11 & 386 & 11.9 & 333 & 9.7 & 301 & 9.2 & 278 & 8.5 & 251 & 7.7 \\
NP NW & 997 & 29.5 & 800 & 24.7 & 825 & 24.1 & 762 & 23.2 & 747 & 22.9 & 731 & 22.6 \\
Total & 3378 & 100 & 3234 & 100 & 3421 & 100 & 3278 & 100 & 3260 & 100 & 3239 & 100
\end{tabular}

Note: $\mathrm{E}=$ employed; $\mathrm{UE}=$ unemployed; NP W = non-participating but willing to work; NP NW = non-participating but not willing to work.

Table A.2

Level of education, 1994 to 1999

\begin{tabular}{|c|c|c|c|c|c|c|c|}
\hline & & $\begin{array}{r}1994 \\
\%\end{array}$ & $\begin{array}{r}1995 \\
\%\end{array}$ & $\begin{array}{r}1996 \\
\%\end{array}$ & $\begin{array}{r}1997 \\
\%\end{array}$ & $\begin{array}{r}1998 \\
\%\end{array}$ & $\begin{array}{r}1999 \\
\%\end{array}$ \\
\hline \multirow[t]{6}{*}{$\mathrm{E}$} & $\mathrm{PE}+\mathrm{LSE}$ & 31.5 & 28.8 & 25.9 & 23.5 & 21.9 & 20.3 \\
\hline & HSE & 45.6 & 46.4 & 48.9 & 49.1 & 49.8 & 49.7 \\
\hline & HVE & 19.0 & 20.4 & 20.4 & 21.4 & 21.6 & 22.8 \\
\hline & UvE & 3.9 & 4.5 & 4.8 & 5.9 & 6.6 & 7.2 \\
\hline & Total & 100 & 100 & 100 & 100 & 100 & 100 \\
\hline & Number & 1866 & 1904 & 2054 & 2058 & 2107 & 2137 \\
\hline \multirow[t]{6}{*}{ UE } & $\mathrm{PE}+\mathrm{LSE}$ & 45.1 & 46.5 & 45.0 & 42.3 & 40.6 & 37.5 \\
\hline & HSE & 41.7 & 38.2 & 36.4 & 35.3 & 38.3 & 41.7 \\
\hline & HVE & 11.1 & 12.5 & 14.8 & 19.2 & 18.8 & 17.5 \\
\hline & UvE & 2.1 & 2.8 & 3.8 & 3.2 & 2.3 & 3.3 \\
\hline & Total & 100 & 100 & 100 & 100 & 100 & 100 \\
\hline & Number & 144 & 144 & 209 & 156 & 128 & 120 \\
\hline \multirow[t]{6}{*}{ NP W } & $\mathrm{PE}+\mathrm{LSE}$ & 48.2 & 46.1 & 43.5 & 45.5 & 43.9 & 42.2 \\
\hline & HSE & 42.0 & 42.0 & 42.3 & 41.9 & 40.6 & 44.6 \\
\hline & HVE & 8.4 & 10.1 & 13.8 & 11.6 & 14.0 & 10.0 \\
\hline & UvE & 1.3 & 1.8 & 0.3 & 1.0 & 1.4 & 3.2 \\
\hline & Total & 100 & 100 & 100 & 100 & 100 & 100 \\
\hline & Number & 371 & 386 & 333 & 301 & 278 & 251 \\
\hline
\end{tabular}

20. All data is drawn from the different waves of the Socio-Economic Panel 1994-1999 (Statistics Netherlands). For more background information about the groups in the Netherlands we refer to ROA (2001). 
Table A.2 (continued)

Level of education, 1994 to 1999

\begin{tabular}{|c|c|c|c|c|c|c|c|}
\hline \multirow[t]{6}{*}{ NP NW } & $\mathrm{PE}+\mathrm{LSE}$ & 64.1 & 61.0 & 62.5 & 58.1 & 58.4 & 51.4 \\
\hline & HSE & 29.2 & 31.8 & 30.3 & 33.1 & 33.6 & 38.7 \\
\hline & HVE & 6.4 & 6.8 & 6.3 & 7.6 & 7.0 & 8.6 \\
\hline & UvE & 0.3 & 0.5 & 0.8 & 1.2 & 1.1 & 1.2 \\
\hline & Total & 100 & 100 & 100 & 100 & 100 & 100 \\
\hline & Number & 997 & 800 & 825 & 762 & 747 & 731 \\
\hline
\end{tabular}

Table A.3

Sample structure of women according to other individual characteristics, 1994 to 1999

$1994 \quad 1995 \quad 1996 \quad 1997 \quad 1998 \quad 1999$

Mean St.Dev Mean St.Dev Mean St.Dev Mean St.Dev Mean St.Dev Mean St.Dev

$\begin{array}{lcccccccccccc}\text { Age } & 40.4 & 12.1 & 40 & 11.6 & 40.7 & 11.8 & 40.8 & 11.6 & 41.1 & 11.6 & 41.5 & 11.4 \\ \begin{array}{l}\text { Hours worked } \\ \text { per week }\end{array} & 25.6 & 12.7 & 25.9 & 12.9 & 25.3 & 12.4 & 25.8 & 12.4 & 25.9 & 11.8 & 25.9 & 11.9 \\ \begin{array}{l}\text { Other income } \\ \text { yearly }\end{array} & 3.9 & 2.7 & 3.7 & 2.4 & 3.8 & 3.0 & 3.8 & 2.7 & 3.7 & 2.5 & 3.8 & 2.4 \\ \begin{array}{l}\text { /10,000) } \\ \text { Net monthly }\end{array} & 1590 & 949 & 1636 & 993 & 1600 & 973 & 1659 & 969 & 1727 & 988 & 1724 & 957 \\ \text { wage }^{b, c} & 14.2 & 4.8 & 14.4 & 5.2 & 14.5 & 5.4 & 14.7 & 5.0 & 15.2 & 5.4 & 15.4 & 5.4 \\ \begin{array}{l}\text { Net hourly } \\ \text { wage }^{b, c}\end{array} & & & & & & & & & & & & \end{array}$

a) Only for women with a child.

b) Only for the working group.

${ }^{c)}$ Guilders per month, 1995 prices.

Table A.4

Average number of children of women, 1994 to 1999

\begin{tabular}{|c|c|c|c|c|c|c|}
\hline $\begin{array}{l}\text { Labour } \\
\text { force states }\end{array}$ & 1994 & 1995 & 1996 & 1997 & 1998 & 1999 \\
\hline E & 0.96 & 0.95 & 0.95 & 0.96 & 0.98 & 1.02 \\
\hline UE & 1.09 & 1.35 & 1.39 & 1.35 & 1.37 & 1.26 \\
\hline NP W & 1.51 & 1.49 & 1.44 & 1.61 & 1.51 & 1.56 \\
\hline NP NW & 1.06 & 1.07 & 0.98 & 0.92 & 0.90 & 0.93 \\
\hline Total & 1.05 & 1.06 & 1.03 & 1.03 & 1.02 & 1.05 \\
\hline
\end{tabular}


Table A.5

Average age of youngest child, 1994 to 1999

\begin{tabular}{lcccccc}
\hline $\begin{array}{l}\text { Labour } \\
\text { force states }\end{array}$ & 1994 & 1995 & 1996 & 1997 & 1998 & 1999 \\
\hline & & & & & & \\
\hline E & 9.5 & 9.4 & 9.5 & 9.3 & 9.1 & 9.4 \\
UE & 10.1 & 8.7 & 8.8 & 9.5 & 9.9 & 9.9 \\
NP W & 8.5 & 8.1 & 8.3 & 8.3 & 8.8 & 8.1 \\
NP NW & 9.5 & 10.1 & 10.1 & 9.9 & 9.9 & 10.2 \\
\hline
\end{tabular}

Table A.6

Percentage of women with at least one child, 1994 to 1999

$\begin{array}{lllllll}\text { Labour } & 1994 & 1995 & 1996 & 1997 & 1998 & 1999\end{array}$

force states

\begin{tabular}{lllllll} 
E & 51 & 51 & 51 & 51 & 53 & 54 \\
UE & 58 & 71 & 71 & 71 & 73 & 65 \\
NP W & 74 & 75 & 73 & 78 & 73 & 73 \\
NP NW & 52 & 53 & 48 & 46 & 45 & 46 \\
\hline
\end{tabular}

Table A.7

Average years of age of women, 1994 to 1999

\begin{tabular}{lcccccc}
\hline $\begin{array}{l}\text { Labour } \\
\text { force states }\end{array}$ & 1994 & 1995 & 1996 & 1997 & 1998 & 1999 \\
\hline & & & & & & \\
E & 36.5 & 36.8 & 37.3 & 37.6 & 37.8 & 38.5 \\
UE & 36.6 & 36.8 & 37.5 & 38.9 & 39.4 & 40.3 \\
NP W & 37.5 & 37.9 & 39.0 & 39.3 & 39.9 & 39.3 \\
NP NW & 49.2 & 49.3 & 50.5 & 50.5 & 51.0 & 51.1 \\
\hline
\end{tabular}

Table A.8

Average yearly other income of women (divided by 10,000), 1994 to 1999

$\begin{array}{lllllll}\text { Labour } & 1994 & 1995 & 1996 & 1997 & 1998 & 1999\end{array}$

force states

\begin{tabular}{lllllll}
\hline & & & & & & \\
E & 3.6 & 3.3 & 3.4 & 3.4 & 3.4 & 3.4 \\
UE & 3.8 & 3.9 & 3.9 & 4.1 & 4.3 & 4.0 \\
NP W & 3.9 & 3.9 & 4.0 & 4.3 & 4.1 & 4.2 \\
NP NW & 4.5 & 4.4 & 4.6 & 4.6 & 4.4 & 4.6 \\
\hline
\end{tabular}





\section{Appendix B}

Table B.1

Estimations of Probit function parameters with Maximum Likelihood

$\begin{array}{llllll}1994 & 1995 & 1996 & 1997 & 1998 & 1999\end{array}$

\begin{tabular}{|c|c|c|c|c|c|c|}
\hline Intercept & -0.41 & -0.05 & -0.22 & 0.57 & -0.02 & 0.03 \\
\hline Age & 0.03 & 0.03 & 0.03 & 0.00 & 0.04 & $0.05 * *$ \\
\hline Age-sq $(* 100)$ & $-0.08 * * *$ & $-0.08 * * *$ & $-0.07 * *$ & $-0.05^{*}$ & $-0.10 * * *$ & $-0.11 * * *$ \\
\hline Age*tenure & 0.15 & 0.02 & 0.03 & -0.02 & 0.02 & $-0.02 * * *$ \\
\hline $\begin{array}{l}\text { Age*tenure-sq } \\
(* 1000)\end{array}$ & -132.50 & 8.94 & -32.74 & 17.37 & 3.69 & $-0.002 * * *$ \\
\hline $\begin{array}{l}\text { Age-sq.*tenure } \\
(* 1000)\end{array}$ & -1.59 & -0.12 & -0.23 & 0.51 & 0.03 & $0.21 * * *$ \\
\hline $\begin{array}{l}\text { Age-sq.*tenure-sq. } \\
(* 100.000)\end{array}$ & 150.80 & -12.30 & 19.40 & -12.10 & 1.74 & $0.03 * * *$ \\
\hline Tenure & 6.08 & 8.60 & 8.12 & 9.39 & 8.09 & $0.54 * * *$ \\
\hline Tenure-sq. & 2.55 & -0.69 & -0.22 & -0.83 & -0.49 & $0.00 * * *$ \\
\hline Alt. income/1000 & $-0.05 * * *$ & $-0.05 * * *$ & $-0.06 * * *$ & $-0.08 * * *$ & $-0.04 * * *$ & $-0.06 * * *$ \\
\hline Child(0-2) & $-0.42 * * *$ & $-0.74 * * *$ & $-0.48 * * *$ & $-0.69 * * *$ & $-0.72 * * *$ & $-0.55 * * *$ \\
\hline Child(3-5) & $-0.41 * * *$ & $-0.53 * * *$ & $-0.41 * * *$ & $-0.46 * * *$ & $-0.68 * *$ & $-0.45^{* * *}$ \\
\hline Child(6-12) & -0.04 & -0.08 & -0.04 & -0.14 & $-0.22 *$ & -0.14 \\
\hline Child(>12) & 0.14 & $0.19^{*}$ & $0.26^{* *}$ & 0.18 & 0.13 & $0.27 * * *$ \\
\hline School(HSE) & $0.16^{* *}$ & $0.26 * * *$ & $0.26^{* * *}$ & $0.27 * * *$ & $0.30^{* * *}$ & $0.33 * * *$ \\
\hline School(HVE) & $0.30^{* *}$ & $0.49 * * *$ & $0.40 * * *$ & $0.37 * * *$ & $0.38^{* * *}$ & $0.56 * * *$ \\
\hline School(UvE) & $0.90 * * *$ & $0.79 * * *$ & $0.78^{* * *}$ & $0.77 * * *$ & $0.81 * * *$ & $0.84 * * *$ \\
\hline $\begin{array}{l}\text { Mean Dependent } \\
\text { var }\end{array}$ & 0.55 & 0.59 & 0.60 & 0.63 & 0.65 & 0.66 \\
\hline SE Regression & 0.29 & 0.32 & 0.30 & 0.29 & 0.30 & 0.35 \\
\hline
\end{tabular}

* Significant at the $10 \%$ level; ** Significant at the 5\% level; *** Significant at the $1 \%$ level 
Table B.2

Estimations of the Wage function parameters.

1994

1995

1996

1997

1998

1999

\begin{tabular}{|c|c|c|c|c|c|c|}
\hline Intercept & $1.36^{* * *}$ & $1.43 * * *$ & $1.57 * * *$ & $1.22 * * *$ & $1.41 * * *$ & $1.84 * * *$ \\
\hline Age & $0.05 * * *$ & $0.05 * * *$ & $0.04 * * *$ & $0.05 * * *$ & $0.05 * * *$ & $0.03 * * *$ \\
\hline Age-sq $(* 100)$ & $-0.06 * * *$ & $-0.05 * * *$ & $-0.04 * * *$ & $-0.06 * * *$ & $-0.05 * * *$ & $-0.02 * *$ \\
\hline Age*tenure & $-0.004 *$ & -0.002 & 0.002 & $-0.004 *$ & -0.003 & 0.0004 \\
\hline $\begin{array}{l}\text { Age*tenure-sq } \\
(* 1000)\end{array}$ & $0.20 *$ & 0.16 & 0.004 & $0.28 * *$ & $0.31 * * *$ & -0.00 \\
\hline $\begin{array}{l}\text { Age-sq.*tenure } \\
(* 1000)\end{array}$ & $0.04 *$ & 0.009 & -0.004 & 0.03 & 0.02 & -0.008 \\
\hline $\begin{array}{l}\text { Age- } \\
\text { sq.*tenure-sq. } \\
(* 100.000)\end{array}$ & $-0.19^{*}$ & -0.11 & 0.05 & $-0.25^{*}$ & $-0.28 * * *$ & -0.00 \\
\hline Tenure & $0.11 * * *$ & $0.09 * *$ & 0.03 & $0.14 * * *$ & $0.11 * * *$ & 0.003 \\
\hline Tenure-sq. & $-0.005 * *$ & $-0.006^{* *}$ & -0.004 & $-0.008 * * *$ & $-0.009 * * *$ & 0.00 \\
\hline $\begin{array}{l}\text { Alt. } \\
\text { income/1000 }\end{array}$ & $0.006^{* *}$ & -0.003 & $0.006^{*}$ & -0.002 & $-0.006^{* *}$ & 0.000 \\
\hline Child(0-2) & 0.03 & $0.11^{* * *}$ & $0.08 * * *$ & $0.08 * * *$ & $0.12 * * *$ & $0.18^{* * *}$ \\
\hline Child(3-5) & 0.004 & 0.05 & -0.04 & 0.04 & -0.02 & $0.06^{*}$ \\
\hline Child(6-12) & $-0.05 * *$ & $-0.07 * * *$ & $-0.04 *$ & -0.03 & -0.01 & -0.003 \\
\hline Child $(>12)$ & $-0.09 * * *$ & $-0.04^{*}$ & $-0.05 * *$ & $-0.05 * *$ & $-0.08 * * *$ & $-0.11 * * *$ \\
\hline School(HSE) & $0.08 * * *$ & $0.11 * * *$ & $0.09 * * *$ & $0.11 * * *$ & $0.10 * * *$ & $0.06^{* * *}$ \\
\hline School(HVE) & $0.24 * * *$ & $0.22 * * *$ & $0.22 * * *$ & $0.28^{* * *}$ & $0.25 * * *$ & $0.21 * * *$ \\
\hline School(UvE) & $0.34 * * *$ & $0.38 * * *$ & $0.39 * * *$ & $0.40^{* * *}$ & $0.39 * * *$ & $0.34 * * *$ \\
\hline InvMills & -0.007 & 0.006 & $0.05 * *$ & $0.06^{* * *}$ & -0.01 & $-0.25 * * *$ \\
\hline Mean & 2.62 & 2.60 & 2.61 & 2.63 & 2.66 & 2.66 \\
\hline Dependent var & & & & & & \\
\hline SE Regression & 0.30 & 0.33 & 0.33 & 0.31 & 0.31 & 0.32 \\
\hline Adj. R-sq. & 0.24 & 0.23 & 0.23 & 0.27 & 0.26 & 0.24 \\
\hline
\end{tabular}

* Significant at the $10 \%$ level; ** Significant at the $5 \%$ level; *** Significant at the $1 \%$ level 


\section{Appendix C}

If policy makers want to stimulate non-participants to find work and working women to work more hours, they could for instance (1) create better and cheaper child care facilities, and (2) stimulate women to become more independent of the income earned by their husbands or male partners, social benefits or alimonies. To see how great the impact of particular policy measures can be for women of distinct labour force states, we simulated a situation in which (1) women do not have any children younger than 20 years old, and (2) women do not have any other income. The first simulation should be regarded as the maximum effect on hours worked of strongly improved child care facilities. Similarly, the results of the second simulation give a clue as to the maximum effect on the hours worked by women if, for example, they have no income support or husband who earns the family income.

Table C.1

Change in number of estimated working hours per group of women, 1994 to 1999

$\begin{array}{cccccc}\text { Mean 1994 } & \text { Mean 1995 } & \text { Mean 1996 } & \text { Mean 1997 } & \text { Mean 1998 } & \text { Mean } 1999 \\ \Delta \mathrm{H} & \Delta \mathrm{H} & \Delta \mathrm{H} & \Delta \mathrm{H} & \Delta \mathrm{H} & \Delta \mathrm{H}\end{array}$

$\begin{array}{lllllll}\begin{array}{l}\text { Simulation 1 } \\ \text { No children }\end{array} & & & & & & \\ & & & & & & \\ \text { Total } & 4.9 & 3.9 & 4.4 & 4.3 & 4.1 & 3.9 \\ \text { E } & 4.5 & 3.7 & 4.1 & 4.1 & 3.9 & 3.6 \\ \text { UE } & 5.2 & 4.1 & 4.7 & 4.6 & 4.4 & 4.1 \\ \text { NP W } & 6.9 & 5.5 & 6.0 & 6.2 & 5.8 & 5.6 \\ \text { NP NW } & 4.6 & 3.8 & 4.1 & 4.1 & 3.9 & 3.8\end{array}$

Simulation 2

No other

income

$\begin{array}{lllllll}\text { Total } & 1.2 & 2.7 & 2.2 & 2.2 & 2.7 & 2.2 \\ \text { E } & 1.1 & 2.5 & 1.9 & 2.1 & 2.4 & 2.1 \\ \text { UE } & 1.2 & 2.7 & 2.1 & 2.2 & 2.7 & 2.2 \\ \text { NP W } & 1.2 & 2.7 & 2.2 & 2.3 & 2.7 & 2.3 \\ \text { NP NW } & 1.4 & 3.2 & 2.4 & 2.5 & 3.0 & 2.6\end{array}$

Note: $\mathrm{E}$ = employed; UE = unemployed; NP $\mathrm{W}$ = non-participating but willing to work; NP NW = non-participating but not willing to work.

Table C.1 shows the average estimated increases of hours of work per group of women. ${ }^{21}$ In the first simulation, the non-participating women who are willing to work (the

21. As before, we estimated the amount of preferred hours by applying the labour supply functions and the wage functions of the different years to the 1994 sample of women. 
'discouraged workers'), showed the largest increase in hours supplied. The increase of their willingness to work was significantly different from the increase of hours of the other groups. Moreover, there were no significant differences between the other three groups. The relatively large increase of estimated hours of work was due to the large average number of children the women of this group had compared to the other groups of women. In every year, they had significantly more children than the other groups (see Tables A.4 and A.6). Besides, they had the youngest children compared to the other three groups (Table A.5). The increase in estimated hours of work may have been large enough to overcome the fixed costs of working, in particular for 'discouraged workers'. This implies that the participation rate of especially these women will rise as a result of improved child care facilities.

In the second simulation, it was assumed that women had no other income of their own or from their husband. The effect on the estimated number of hours supplied was the smallest for working women. There was a significant difference (at the $1 \%$ level) between working and non-working women, but this did not hold for the differences between the three groups of non-working women. Table A.8 shows that working women indeed had a lower average other income than the women of the other three groups. When other income decreases, unemployed women may be willing to accept a job for more hours per week, thereby increasing their chances on the labour market. Moreover, due to a lower other income, 'discouraged workers' may be stimulated to search for a job (i.e. they will be part of the labour force), since the hours they are willing to supply themselves on the labour market may become higher than the minimum number of working hours required to overcome the fixed costs of working. This leads to a rise of the participation rate of these women.

If 1999 is compared to 1994, it seems that the impact of the above-mentioned measures to stimulate female participation on the labour market is reduced in the first simulation, which may be a result of growing female independence with regard to having children. Moreover, for the second simulation the impact of having no other income seems to have increased, which may point to a larger willingness of women to work and earn their own income. Nevertheless, for both simulations there was some variation in the additional number of hours women are willing to work for the years between 1994 and 1999 


\section{Appendix D}

Table D.1

Estimated average number of hours supplied for women of four distinct labour force states, 1994$1999^{22}$

Mean 1994 Mean 1995 Mean 1996 Mean 1997 Mean 1998 Mean 1999

\begin{tabular}{lcccccc}
\hline Total & 17.4 & 19.0 & 18.0 & 19.1 & 20.1 & 21.6 \\
E & 25.6 & 25.9 & 25.3 & 25.8 & 25.9 & 25.9 \\
UE & 13.8 & 13.8 & 12.3 & 13.3 & 14.6 & 19.5 \\
NP W & 11.1 & 12.5 & 10.7 & 11.2 & 13.5 & 17.3 \\
NP NW & 5.0 & 6.9 & 4.5 & 5.1 & 6.9 & 11.1 \\
& & & & & & \\
\hline
\end{tabular}

Table D.2

Estimated average number of hours supplied for women with 1994 wage functions and individual characteristics, and labour supply functions for the years 1994-1999

Mean 1994 Mean 1995 Mean 1996 Mean 1997 Mean 1998 Mean 1999

\begin{tabular}{lcccccr}
\hline & & & & & \\
Total & 17.4 & 17.7 & 16.5 & 16.9 & 17.7 & 18.4 \\
E & 25.6 & 26 & 25 & 25.3 & 25.2 & 26.7 \\
UE & 13.8 & 14 & 12.7 & 13.5 & 14.8 & 15.4 \\
NP W & 11.1 & 11.4 & 10.2 & 10.8 & 12.4 & 12.8 \\
NP NW & 5.0 & 5.2 & 3.3 & 3.8 & 6.0 & 5.6 \\
\hline
\end{tabular}

Table D.3

Estimated average number of hours supplied for women with 1994 labour supply functions and individual characteristics, and wage functions for the years 1994-1999

Mean 1994 Mean 1995 Mean 1996 Mean 1997 Mean 1998 Mean 1999

\begin{tabular}{lcccccc}
\hline & & & & & & \\
Total & 17.4 & 17.1 & 17.3 & 17.2 & 17.2 & 16.7 \\
E & 25.6 & 25.3 & 25.2 & 25.2 & 25.5 & 25.8 \\
UE & 13.8 & 13.2 & 13.4 & 13.4 & 13.2 & 11.8 \\
NP W & 11.1 & 10.6 & 10.7 & 10.9 & 10.6 & 9.1 \\
NP NW & 5.0 & 4.8 & 5.6 & 5.1 & 4.7 & 3.4 \\
\hline
\end{tabular}

22. Note: $\mathrm{E}=$ employed, $\mathrm{UE}=$ unemployed, $\mathrm{NP} \mathrm{W}=$ non-participating but willing to work, $\mathrm{NP} \mathrm{NW}=$ nonparticipating but not willing to work. 
Table D.4

Estimated average number of hours supplied for women with 1994 individual characteristics, and wage and labour supply functions for the years 1994-1999

Mean 1994 Mean 1995 Mean 1996 Mean 1997 Mean 1998 Mean 1999

\begin{tabular}{lcccccc} 
Total & 17.4 & 17.7 & 16.5 & 16.9 & 17.7 & 18.2 \\
E & 25.6 & 25.9 & 24.9 & 25.2 & 25.4 & 27.2 \\
UE & 13.8 & 13.6 & 12.5 & 13.4 & 14.5 & 14.0 \\
NP W & 11.1 & 11.2 & 10.1 & 10.8 & 12.1 & 11.3 \\
NP NW & 5.0 & 5.2 & 3.9 & 4.0 & 5.9 & 4.4 \\
\hline
\end{tabular}

